\title{
BACTERIAL INOCULANTS FOR TOMATO SEED TREATMENT
}

\author{
Oana-Alina Boiu-Sicuia ${ }^{1,2} *$, Sorina Dinu ${ }^{1}$, Lavinia-Diana-Nicoleta Barbu ${ }^{1,2}$ \\ ${ }^{1}$ Research-Development Institute for Plant Protection, 8 Ion Ionescu de la Brad Blvd., Bucharest, Romania \\ ${ }^{2}$ University of Agronomic Sciences and Veterinary Medicine - Bucharest, Faculty of Biotechnology, \\ 59 Mărăşti Blvd., Bucharest, Romania
}

\begin{abstract}
Tomatoes are important vegetables in Romanian greenhouse and open field production. Improving their growth is a continuous concern that begins with seed germination and seedlings production and covers all culture types, conventional and organic. Microbial inoculants are valuable products that can trigger both growth promotion and plant protection. This study presents the beneficial traits of some bacterial inoculants applied as seed treatment on tomatoes. The tested inoculants contain single strains or a mixture of two beneficial bacteria, Bacillus amyloliquefaciens and Paenibacillus graminis. These bacterial treatments improve several growth parameters such as: plant fresh and dry weight, root length and branching. Although, the bacterial seed treatments delay plant emergence, the treatment stimulate later growth, revealing increased biomass weight. Compared to the untreated control, the mixt bacterial treatment improved plant fresh weight with $38.1 \%$ and the dry weight with $48.3 \%$. Due to the biologic activity of these beneficial bacteria on plant growth, the mixed microbial inoculant offers similar benefits to a complex commercial fertilizer used for horticultural purposes.
\end{abstract}

Keywords: Bacillus amyloliquefaciens, Paenibacillus graminis, tomato seed treatment.

\section{INTRODUCTION}

Tomatoes are important vegetables in Romanian greenhouse and open field production. Due to the governmental support of tomato growers through the "tomato program", the total harvested area for tomatoes started to grow from 40041 ha in 2017 to 40741 ha in 2018 and 45700 ha in 2019, respectively (https://gov.ro).

Improving tomato growth is a continuous concern for both farmers and agricultural researcher (Passari et al., 2019). Growth promotion and yield improvement start from seed germination and seedlings production, and reach the final harvest. These cover all culture types, conventional as well as organic (Wang et al., 2020; Ye et al., 2020).

Microbial inoculants are valuable products that can trigger both growth promotion, yield increases and plant protection attributes (Mayak et al., 2004; Haney et al., 2015; Răut et al., 2017; Kong et al., 2018; Ferreira et al., 2019). Therefore, the aim of this paper is to present the beneficial traits of some bacterial inoculants applied as tomato seed treatment. The tested inoculants contain Bacillus amyloliquefaciens OS17 and Paenibacillus graminis FL400 plant-beneficial bacteria, either as single strains or as bacterial mixture. 


\section{Current Trends in Natural Sciences}

Vol. 9, Issue 17, pp. 284-288, 2020

https://doi.org/10.47068/ctns.2020.v9i17.035

Current Trends in Natural Sciences (on-line)

ISSN: 2284-953X

Current Trends in Natural Sciences (CD-Rom)

ISSN: 2284-9521

ISSN-L: 2284-9521

ISSN-L: 2284-9521

\section{MATERIALS AND METHODS \\ Bacterial strains}

Bacillus amyloliquefaciens OS17 and Paenibacillus graminis FL400 are selected strains from the RDIPP microbial collection. These strains were also registered in international microbial collection NCAIM, under the numbers (P) B.001415 and (P) B.001365 respectively, and patented at the Romanian State Office for Inventions and Trademarks (OSIM).

\section{Bacterial formulation}

Bacteria were grown in LuriaBertani broth for 3 days, under continuous shaking at $28^{\circ} \mathrm{C}$. Cells' biomass was harvested separately for each strain and pellets were resuspended in sterile phosphate buffer. The bio-products were maintained as single strain inoculants or as a consortium of mixed strains $(1: 1 \mathrm{v} / \mathrm{v})$. Bacterial inoculants were then supplemented with carboxy-methyl-cellulose, at a final $2 \%$ concentration. Each inoculum was standardized at a final concentration of $10^{8} \mathrm{cfu} / \mathrm{ml}$ (figure 1).

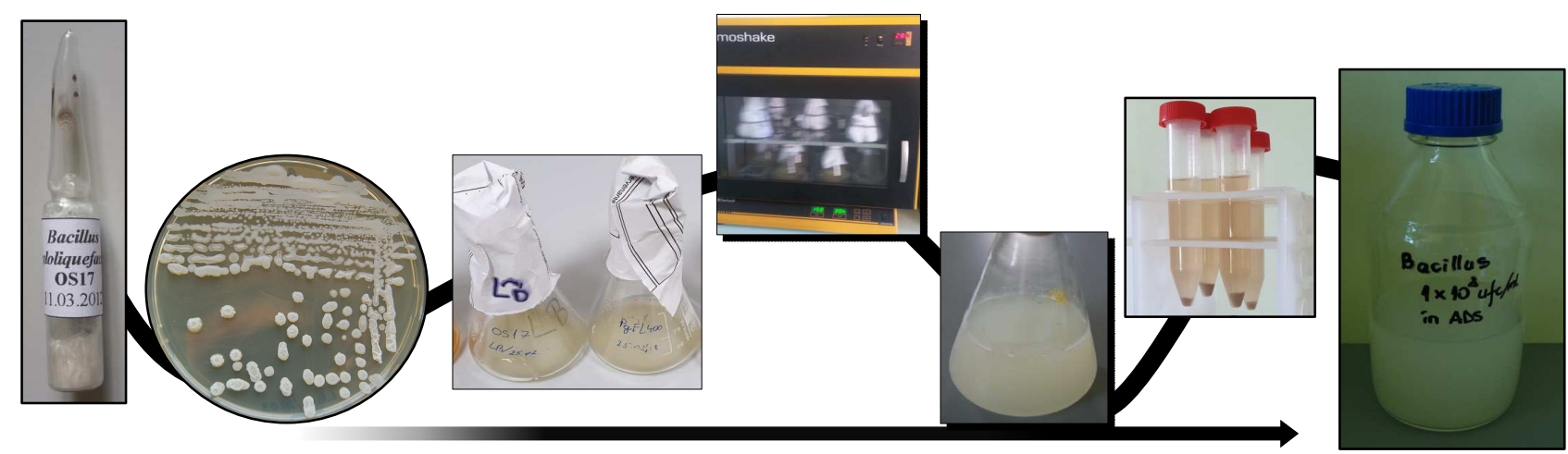

Figure 1. Important stages in bacterial growth and bio-products formulation

\section{Plant growth conditions}

The plant growth promotion tests were carried out on tomatoes (Lycopersicon esculentum Mill.) Buzău 1600 variety. The freshly prepared bacterial inoculants were applied as seed treatments. Five experimental variants were studied:

$\mathrm{V} 1=$ Untreated control

$\mathrm{V} 2=$ Bacillus amyloliquefaciens OS17

V3 = Paenibacillus graminis FL400

V4 = Mixed treatment (OS17 and FL400)

V5 = CropMax (comercial fertilizer)

Seeds were germinated in Cyg pouches (figure 2) incubated in Sanyo MLR351H growth chamber for 30 days under 16 hours photoperiod, $26^{\circ} \mathrm{C} /$ light, $20^{\circ} \mathrm{C} /$ dark, $14000 \mathrm{~lx}$ and $70 \% \mathrm{RH}$, using PNS (plant nutrient solution) for basic ferti-irrigation. 


\begin{tabular}{lcr}
\hline & $\begin{array}{c}\text { Current Trends in Natural Sciences } \\
\text { Vol. 9, Issue 17, pp. 284-288, 2020 }\end{array}$ \\
& $\begin{array}{l}\text { Current Trends in Natural Sciences (CD-Rom) } \\
\text { https://doi.org/10.47068/ctns.2020.v9i17.035: 2284-9521 }\end{array}$ \\
\cline { 2 - 3 } Current Trends in Natural Sciences (on-line) & ISSN- & ISSN-L: 2284-9521 \\
ISSN: 2284-953X & \\
ISSN-L: 2284-9521 &
\end{tabular}
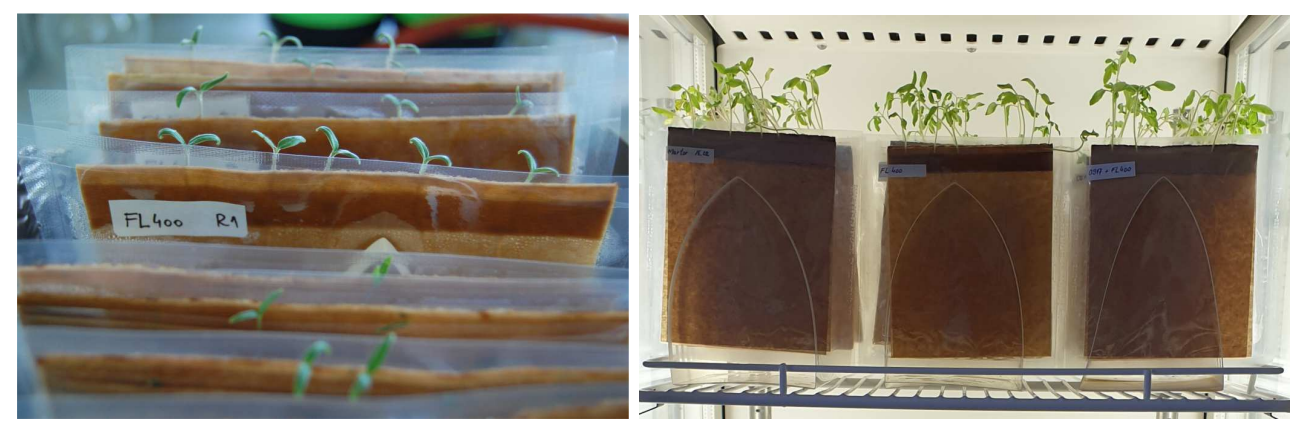

Figure 2. In vitro grown tomatoes in Cyg pouches: emerged (a) and young (b) seedlings

One month after seeding, several biometric measurements were performed, such as tomato shoots length and fresh and dry weight of the plants.

\section{RESULTS AND DISCUSSIONS}

Tomato plants emerged five to seven days after sowing, depending on the seed treatment. Bacterial treatments delayed seeds germination by one to two days, compared to the untreated control. One month after seeding, shoots length was measured. No significant differences were noticed between untreated control, B. amyloliquefaciens OS17 seed treatment and CropMax fertilizer regarding shoots length. Shoots were, however, higher if the seed was treated with mixed bacterial inoculum of B. amyloliquefaciens OS17 and P. graminis FL400 strains (figure 3).

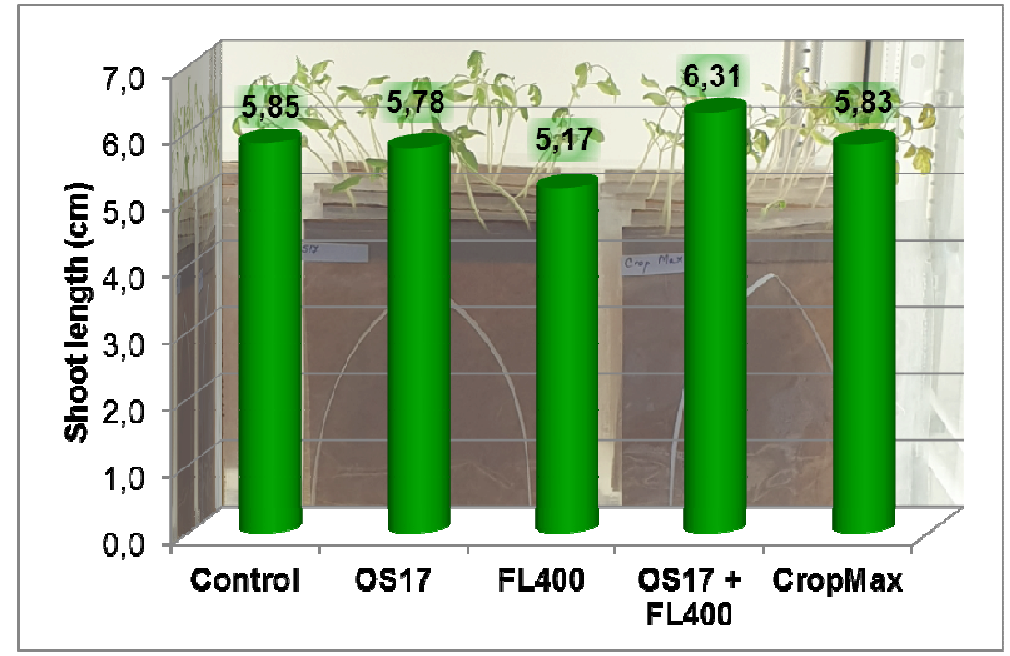

Figure 3. Tomato shoot length one month after seeding in Cyg pouches

Greener leaves effect and deeper roots were observed in CropMax fertilized tomatoes and mixed bacterial treatment (figure 4d), revealing a robust growth. Deeper roots could give some beneficial attributes to the plants in a classical growth system, were tomatoes are directly sown in the field (and the root tip is not chiselled as in seedlings production). Such root growth could help the plants to explore deeper soil layers, and possible soil water reserves, increasing plant adaptation in nonirrigated or drought conditions. 


\begin{tabular}{|c|c|}
\hline & $\begin{array}{c}\text { Current Trends in Natural Sciences } \\
\text { Vol. 9, Issue 17, pp. 284-288, } 2020 \\
\text { https://doi.org/10.47068/ctns.2020.v9i17.035 }\end{array}$ \\
\hline $\begin{array}{l}\text { Current Trends in Natural Sciences (on-line) } \\
\text { ISSN: 2284-953X } \\
\text { ISSN-L: 2284-9521 }\end{array}$ & $\begin{array}{r}\text { Current Trends in Natural Sciences (CD-Rom) } \\
\text { ISSN: 2284-9521 } \\
\text { ISSN-L: 2284-9521 }\end{array}$ \\
\hline
\end{tabular}
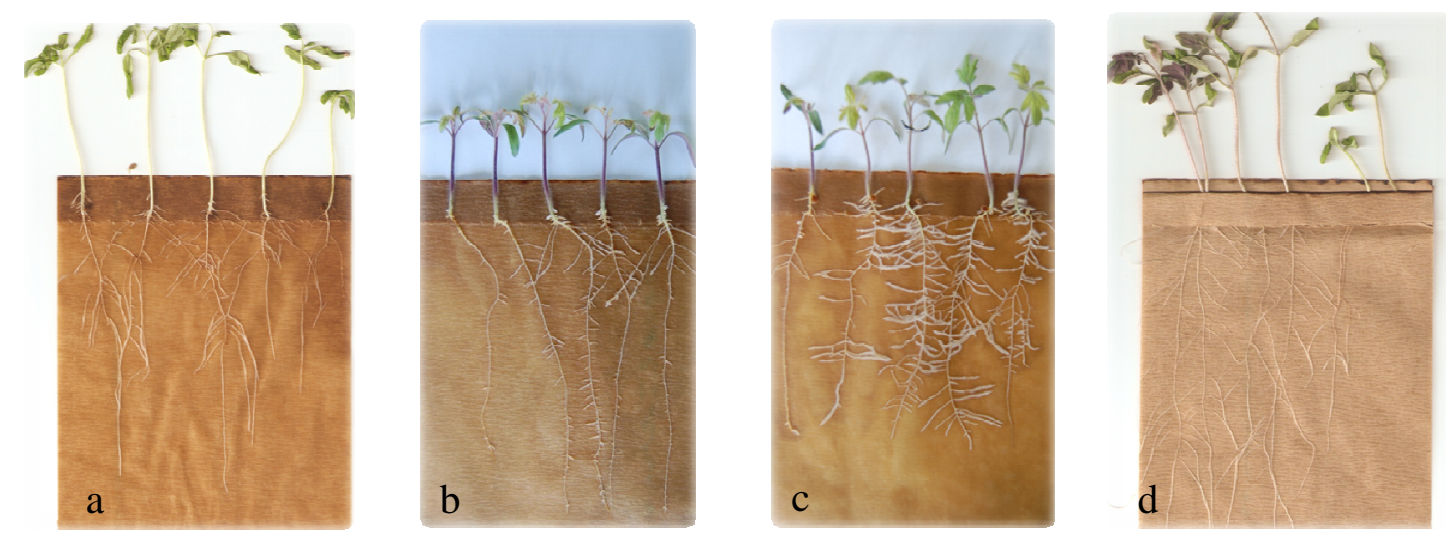

Figure 4. Comparative growth of tomato seedlings

The bacterial seed treatments substantially increased root branching (figures $4 \mathrm{~b}$, c) compared to the untreated control (figure a). Such root growth improvement gives important advantages to the plants in any growth system, either soil or soil-less; directly sown or seedling planted cultures. Welldeveloped root systems increase plant sustainability and improve water and nutrient uptake.

Bacterial treatments also promoted plant vigour. Biomass fresh and dry weights were improved by bacterial seed treatments (figure $5 \mathrm{a}, \mathrm{b}$ ). The mixed treatment revealed a synergic effect between the two plant beneficial strains.
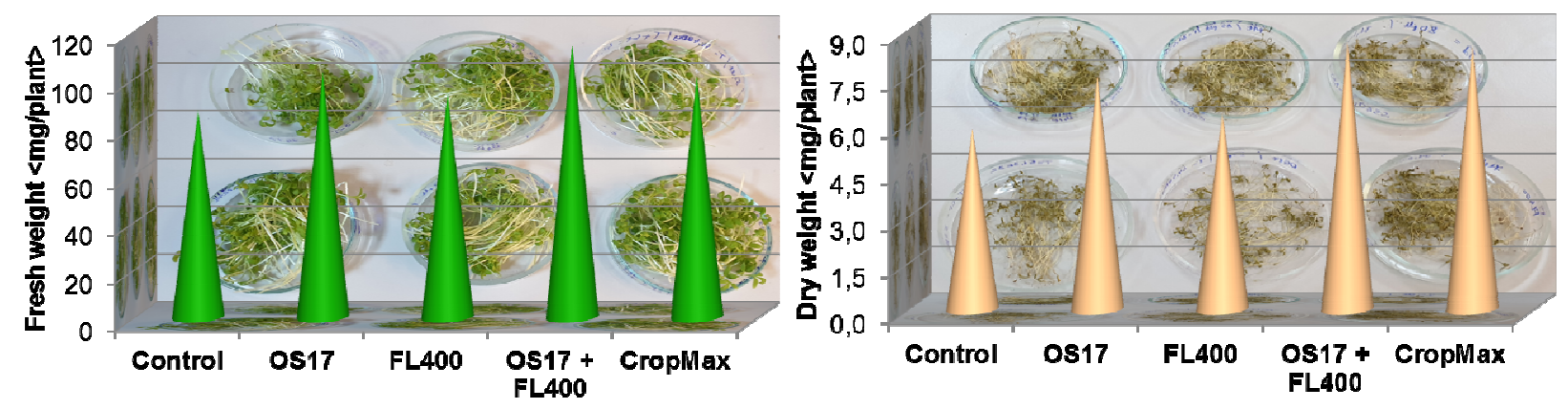

Figure 5. Tomato fresh (a) and dry (b) weight of one month plants

Best results were obtained the mixed bacterial seed treatment based on OS17 and FL400 strains for both fresh (114 mg/plant) and dry $(8.6 \mathrm{mg} /$ plant $)$ plant weight.

\section{CONCLUSIONS}

$>$ Bacillus amyloliquefaciens OS17 and Paenibacillus gramins FL400 are having synergic effects when applied together as tomato seed treatments.

$>$ Bacterial seed treatments delay plant emergence but stimulate later growth, revealed as fresh and dry biomass weight.

$>$ Mixed seed treatment with OS17 and FL400 beneficial strains improved plant growth similarly to CropMax commercial fertilizer. 


\section{ACKNOWLEDGEMENTS}

This work was supported by a grant of the Romanian Ministry of Research and Innovation, CCCDI UEFISCDI, project number PN-III-P1-1.2-PCCDI-2017-03-01/28PCCDI/2018, within PNCDI III.

\section{REFERENCES}

Ferreira, C., Soares, H., Soares, E. (2019). Promising bacterial genera for agricultural practices: An insight on plant growth-promoting properties and microbial safety aspects. Science of The Total Environment, 682, 779-799. https://doi.org/10.1016/j.scitotenv.2019.04.225

Haney, C.H., Samuel, B.S., Bush, J., Ausubel, F.M. (2015). Associations with rhizosphere bacteria can confer an adaptive advantage to plants. Nature Plants, $1,15051$.

https://gov.ro/ro/print?modul=subpagina\&link=nota-de-fundamentare-hg-nr-248-26-03-2020. Nota de fundamentare la HG 248/ 2020-03-26 privind aprobarea schemei „Ajutor de minimis pentru aplicarea programului de susţinere a produsului tomate în spații protejate“ pentru anul 2020. [Substantiation note for GD 248/2020-03-26 regarding the support scheme "Minimis aid for the application of tomato product program in greenhouses" for 2020]. Publicată în Monitorul Oficial al României nr 272 din 2020-04-01.

Kong, Z., Hart, M., Liu, H. (2018). Paving the way from the lab to the field: using synthetic microbial consortia to produce high-quality crops. Frontiers in Plant Science 9, 1467.

Mayak, S., Tirosh, T., Glick, B. (2004). Plant growth-promoting bacteria that confer resistance to water stress in tomatoes and peppers. Plant Science., 166, 525-530. 10.1016/j.plantsci.2003.10.025.

Oancea, F., Dinu, S., Popescu, A., Mathe, I., Abraham, B., Lanyi, S. (2013). Tulpină de Paenibacillus graminis care favorizează nodularea plantelor leguminoase. [Paenibacillus graminis strain improving leguminous plant nodulation]. OSIM Patent no. 125651/30.04.2013.

Passari, A.K., Upadhyaya, K., Singh, G., Abdel-Azeem, A.M., Thankappan, S., Uthandi, S., Hashem, A., Abd Allah, E.F., Malik, J.A., As, A., Gupta, V.K., Ranjan, S., Singh, B.P. (2019). Enhancement of disease resistance, growth potential, and photosynthesis in tomato (Solanum lycopersicum) by inoculation with an endophytic actinobacterium, Streptomyces thermocarboxydus strain BPSAC147. PloS one, 14(7), e0219014. https://doi.org/10.1371/journal.pone.0219014

Răut, I., Oancea, F., Trinidad, A.B.L.S., Călin, M., Constantinescu-Aruxandei, D., Badea Doni, M., Arsene M.L., Vasilescu, G., Şesan, T.E., Jecu, L. (2017). Evaluation of Trichoderma spp. as a biocontrol agent against Phytophthora parasitica. Scientific Bulletin. Series F. Biotechnologies, XXI, 179-182.

Saad, M., Eida, A.A., Hirt, H. (2020). Tailoring plant-associated microbial inoculants in agriculture: A roadmap for successful application. Journal of Experimental Botany, eraaa111, doi:10.1093/jxb/eraa111

Sicuia, O., Constantinescu, F., Dinu, S., Oancea, F. (2017). Tulpină de Bacillus amyloliquefaciens cu potențial de utilizare ca agroinoculant în substraturile cu risc fitosanitar ridicat şi ameliorator al terenurilor contaminate cu hidrocarburi. [Bacillus amyloliquefaciens strain with potential use as agroinoculant for growth substrate with high phytosanitary risks, or soil improver in PHC contaminated lands]. OSIM Patent no.129512 / 29.09.2017.

Wang, J., Niu, W., Li, Y. (2020). Nitrogen and phosphorus absorption and yield of tomato increased by regulating the bacterial community under greenhouse conditions via the alternate drip irrigation method. MDPI, Agronomy, 10, 315; doi:10.3390/agronomy 10030315

Ye L., Zhao, X., Bao, E., Li, J., Zou, Z., Cao, K. (2020). Bio-organic fertilizer with reduced rates of chemical fertilization improves soil fertility and enhances tomato yield and quality. Scientific Reports, 10, 177. https://doi.org/10.1038/s41598-019-56954-2 